\title{
Inclusive growth, human capital development and natural resource rent in SSA
}

\author{
Ibrahim D. Raheem ${ }^{1}$ Kazeem O. Isah ${ }^{2}$ • \\ Abdulfatai A. Adedeji ${ }^{3}$
}

Received: 8 November 2015/Accepted: 29 August 2016/Published online: 17 September 2016

(C) The Author(s) 2016. This article is published with open access at Springerlink.com

\begin{abstract}
This paper seeks to achieve two objectives. First, we argued for the increase in government expenditure on education and health to examine the possibility of achieving inclusive growth. Second, financing gap model was employed to estimate the potential growth in GDP per capita that is accruable to the economy if government use natural resource rent to finance increase in expenditure of education and health. Relying on dataset for 18 SSA countries, among the results obtained showed that both government expenditures are found to be significant for explaining growth in SSA. However, augmenting health expenditure with natural resource appears to be more significant for making growth process inclusive. Also, the results of the simulation exercise indicate that increasing government expenditure on health would increase GDP per capita growth by over $3.1 \%$. The policy implication of this is drawn based upon the results obtained.
\end{abstract}

Keywords Inclusive growth - Education and health expenditures · Natural resource rents $\cdot$ Financing gap model and Sub Saharan Africa

\section{Introduction}

A layman would have an eye-catching and appealing picture of natural resource abundance. But a closer and scientific investigation of the effects of natural resources on both the macro- and socio-economic variables would suggest otherwise. For instance, natural resource abundance has been found to fuel growth

Ibrahim D. Raheem

idr5@kent.ac.uk

1 School of Economics, University of Kent, Canterbury, UK

2 Centre for Econometrics and Allied Research, University of Ibadan, Ibadan, Nigeria

3 Department of Economics, University of Ibadan, Ibadan, Nigeria 
"exclusiveness". The entire supply chain of natural resources from discovery to sales has features of growth elitism. As an illustration, governments or their appointees hold property rights to natural resource wealth, in which case, the immediate effect of the supply chain is self-enrichment of the property rights holders. Second, in a case where the private sector is allowed to be among the stakeholders, selfish interest of the government through excessive taxation might discourage investment required to discover natural resources in the first place. Another channel is if the political elite or other powerful groups were given preferential access to the resource wealth, they would use it for their own benefit without investing the generated wealth for overall growth (Warner 2012).

Also, the exact macroeconomic effect of natural resource abundance is difficult to unravel. In the short term, there is existence of volatility in the revenue accruable from the exploitation, exploration and sales of these resources. This makes it difficult to conduct macroeconomic stabilization policies. The long run challenge relates to the ample evidences that have shown that resource-endowed countries tend to have slower economic growth rate as compared with resource-scarce countries (Frankel 2012; Oyinlola et al. 2015; Arezki and Nabli 2012). This strand of the literature is referred to as "Resource Curse Hypothesis" (RCH), a coinage attributed to Sachs and Warner (1995). It should be noted that the RCH debate is inconclusive, as studies have argued and documented evidences on both sides of the argument (See Frankel 2012 for a survey).

The problem identified by the studies that have refuted $\mathrm{RCH}$ is due to the fact that they concentrate on aggregate growth. These studies have an implicit assumption that all the citizens enjoy the rents received from the sales/export of these resources, which is the hardly the case in reality. In the sub-Saharan African (SSA) case, there are ample evidences that have proved that a selected proportion of the population, mostly the political elite and urban dwellers, enjoy these proceeds. Also, a large chuck of this revenue is spent on recurrent and administrative expenditures, which is biased against the poor and unemployed. Thus, this being the case is an indication that these categories of citizenry (i.e. the poor and unemployed) are potentially being deprived from reaping the benefits of the endowment. ${ }^{1}$ This among others might limit the ability of these sets of citizens to contribute their productivity quota to the national output. Hence, it could then be summarily stated that natural resource abundance would not lead to inclusive growth, ${ }^{2}$ as this might be a plausible

\footnotetext{
${ }^{1}$ Caution must be exercised here, in that we are not making a case of total deprivation by these two categories of citizenry. We are, however, inferring that in cases where government performs its right to these people (the poor and unemployed), it is either low quality infrastructural facilities are provided, or project never reached the completion stage-where citizens can have access and use such facilities. This is just as Arezki et al. (2012) concluded that "investment" in the quality of public investment should be given utmost importance and priority.

${ }^{2}$ Ianchovichina and Gable (2012) defined inclusive growth as the one that aims to sustainably and rapidly reduce poverty and inequality and ensures that all the labour force contribute to and benefit from economic growth process. This can be achieved through providing a level playing field for investment and increasing productive employment opportunities. In a similar vein, Warner (2012) also discussed the concept of growth inclusiveness as the one in which income of lower-income groups grow relatively faster and that no social group(s) is/are left behind in the economic growth process. This concept would be further explored in succeeding sections of the study.
} 
candidate in explaining the $\mathrm{RCH}$. The existence of inclusive growth ensures that all the sections of the country are active in the growth process of the economy. To this end, there would be increase in the tax-based revenue of the government, through increase in job creation. Hence, government would have more funds to formulate and implement developmental policies.

The importance of inclusive growth has been demonstrated on a global, regional and national levels. A classical example is the tagging of the World Economic Forum that was held in Nigeria Forging Inclusive Growth, Creating Jobs; in February 2014, UK's Department for International Development (DFID) highlighted inclusive growth as part of work plans and strategies. Also, in May 2014, European Commission emphasized the important role of the private sector led strategy in achieving inclusive growth. Nigeria's 2013 Federal Government Budget was coined 'Fiscal Consolidation with Inclusive Growth'; in November 2013, the International Monetary Fund (IMF) set inclusive growth as a pivotal part of their research agenda for 2014. ${ }^{3}$ To further demonstrate the importance of inclusive growth, Organization for Economic Cooperation and Development (OECD) and United Nations Development Programme (UNDP) have actively been engaging in coming up with policy papers geared towards enhancing inclusive growth. Examples of such papers include OECD (2012) whose report identified three problems: poverty, ${ }^{4}$ unemployment ${ }^{5}$ and inequality, ${ }^{6}$ that growth from 1990 s to date had failed to tackle. OECD (2013a, b, c) also emphasizes the importance of inclusive growth. Goal 8 of the proposed Open Working Group on Sustainable Development Goal is related to inclusive growth. G20 (2013) have confirmed the absence of inclusive growth in the region and further argued not only for a strong, sustainable and balanced growth but also for a more inclusive pattern of growth that will mobilize the talents of the citizenry. Also, Anand et al. (2013) argued that the Arab Spring, the growing divide between Main Street and Wall Street in advanced economies, and the "three speed" world economy have placed inclusive growth at the forefront of policy debates.

In this study, we make a case for Human Capital Development (HCD) as a likely and efficient candidate/mechanism to ensure and enhance inclusive growth. HCD is a broad concept and cannot be measured holistically. However, we postulate that education and health are key indicators of HCD. This claim has also been backed by the fact that they (education and health) have retained their prominence by being

\footnotetext{
${ }^{3}$ Even though efforts have been made by IMF to shed light on inclusive growth prior to the November 2013 meeting. Studies such as Arezki and Nabli (2012), Arezki, Dupuy and Gelb (2012), Heuty (2012), Ianchovichina and Gable (2012) and Warner (2012) have confirmed the believe of IMF in inclusive growth.

4 World Bank (2006) as cited in CAFOD (2014) stated that not all growth are poverty-reducing. Despite the impressive growth at the turn of the 20th century, over 1.2 billion (24\%) of the world's population live below $\$ 1.25$ a day.

5 World Bank (2013) stated that excess of 200 million world population are out of job and about 600 million jobs need to be generated in the next 15 years to keep the current level of employment constant.

6 The OECD (2013b) has explained that the gap between the rich and poor is widening almost everywhere and the current level is widest in the last 30 years amongst the OECD member countries. Oxfam (2014) analyzed that the top 85 richest people in the world own the same amount of wealth as the bottom half of the world population (i.e. 1.3 billion people)!.
} 
among the nine objectives of Millennium Development Goals (MDGs) and recently, Sustainable Development Goals (SDG). Also, agencies such as United Nations Educational, Scientific and Cultural Organization (UNESCO), OECD, UNDP and World Health Organization (WHO) have advocated for the improvement in the quality of service delivery as well as increase in government expenditures on these sectors.

Based on the foregoing, this study seeks to achieve two broad objectives. Firstly, to empirically examine the possibility of achieving inclusive growth through increase in government expenditures on health and education. The second objective is to examine the potential benefit of investing the natural resources rent on HCD indicators. To this end, the study uses financing gap model and simulation methodology under certain assumptions to estimate the potential economic growth accruable by investing natural resource rent on human capital indicators.

The novelty this study brings forth is based on its objective. Most of the existing papers on inclusive growth are policy papers, which is less empirical, as it is not driven by econometric or other scientific approaches. ${ }^{7}$ The scope of this study is limited to 18 SSA countries for the period 1995-2013. The reasons adduced to limiting the scope to SSA are because (1) with the exception of very few countries (Botswana, Namibia and may be South Africa), statistics have shown that resourcerich countries in SSA are ensnared with $\mathrm{RCH}$; (2) resource rents have been the major source of revenue for SSA countries; (3) the region is the least in the global HDI rankings and (4) the region has the highest prevalence of poverty and inequality. The selected countries are based on data availability.

The rest of the paper is structured as follows: section two dwells on inclusive growth issues and further argued for the beneficial effects of inclusive growth. In section three, we discuss the data and provide a detailed trend analysis of the key variables in the study. Model specification and methodological related issues are offered in section four. Sections five and six house the empirical result and conclusion respectively.

\section{Expositions on inclusive growth}

It is the intention of this section to provide a general overview of inclusive growth, by examining its definitions/meaning, determinants as well as measurement.

\subsection{Concept of inclusive growth}

More than ever before, institutions, governments and organizations have been actively talking about inclusive growth. This is a fall out of the fact that it has been observed that increase in income (GDP) of countries does not necessarily mean growth in the first instance, not to talk of sustainable growth. This notion is justified because in most developing countries, there is high unemployment rate, wide

\footnotetext{
7 We acknowledge that Warner (2012) was quite empirical, the point of divergence is on the premise that Warner focused on the labour side of inclusive growth.
} 
income disparity as well as increasing rate of poverty. Despite this, such countries still record incidence of growth. Hence, the growth recorded is the product of a section of the population and not the entire population. To ensure justice and equity, the burgeoning arguments have tilted towards ensuring that all economic agents contribute their quota to the growth process of their country.

Although, there is no absolute acceptable definition of inclusive growth, a situation that cut across all branches of economics in agreeing to common definition(s) of any term, there is however, near unison in terms of what inclusive growth generally meant. ${ }^{8}$ As the term "inclusive", which means all; entire; total and whole, inclusive growth could then be defined as the one that aims to ensure that all income, social and economic groups/agents contribute their quota in the growth process of an economy. Based on this concept, it could be inferred that inclusive growth tends to mainly solve socio-economic/developmental problems such as poverty, inequality and unemployment. It could also be argued that the economic growth that solves these problems is inclusive in nature. For instance, a classical example of inclusive growth could be the one that the wage rate is higher than per capita income (GDP per capita) and/or economic growth is accompanied by fall in poverty rate, unemployment and inequality gap. However, it should be noted that inclusive growth is conditioned upon continuity/sustainability. That is, such growth must have a steady and relatively stable trend.

In order to have a sound understanding of the concept of inclusive growth, we limit our review to the two leading advocates of inclusive growth-the OECD and UNDP. Starting with the OECD, special attention was devoted to the socioeconomic adversities (unemployment, inequality and poverty) confronting the global economy. They defined inclusive growth as the one that reduces poverty and inequality and benefits the most marginalized section of the population. The povertyinequality-growth debate has long been contested and this study does not attempt to delve into it. Rather, it attempts to demonstrate how this debate might lead to inclusive growth. Inclusive growth is linked to the debate in that it proves to the governments that growth is just a process and not an end (i.e. it is a mere necessary but not sufficient condition for long-term development). Growth should be seen as a tool to achieving wider objectives. ${ }^{9}$ Emphasis must be placed on the quality of

\footnotetext{
${ }^{8}$ Institutions and organizations such as the World Bank, OECD, Asian Development Bank (ADB) and UNDP perceive inclusive growth differently, as such, its components differ across these institutions. For instance, $\mathrm{ADB}$ had criticized existing definitions as “... vague and do not lend themselves to easy quantitative operationalization, whilst others are quite specific but do not capture the essence of the concept...". Ali and Son (2007) defined growth as inclusive if it increases the social opportunity function, which depends on two factors: (1) average opportunities available to the population, and (2) how opportunities are shared among the population. In essence, they define inclusive growth as growth that not only creates new economic opportunities, but also one that ensures equal access to the opportunities created for all segments of society, particularly for the poor. The inability to have a clear-cut definition might be due to the fact that the concept "inclusive growth" does not have a theoretical foundation, and to a large extent, is country specific (Addison and Niño-Zarazúa 2012).

9 Ravallion (2009) and World Bank (2012) found that low-income countries (<\$700 GDP per capita) should prioritize growth because the available capital is not sufficient to redistribute or to reduce incidence of poverty. However, high-income countries should patronize pro-poor policy because inequality would dampen the growth and as such would not be able to reduce poverty (Chandy and Penciakova 2013; COFOD 2014).
} 
growth rather than quantity. Also, it helps to erase the notion that growth would eradicate these socio-economic problems. Hence, concerned stakeholders are put on their toes to forge policies that would enhance poverty and inequality-resistant growth.

\subsection{Determinants of inclusive growth}

Irrespective of the fact that inclusive growth has varying definitions across organizations, there are however, some common positions as regard its determinants. Using the concept of OECD and UNDP, it could be simply summarized that HCD indicators as well as other socioeconomic variables serve as valid and strong determinants of inclusive growth. To this end, variables such as investment in human capital, ${ }^{10}$ job creation, structural transformation and broad-based growth, ${ }^{11}$ good institutions ${ }^{12}$ and social protection ${ }^{13}$ have been found to aid the desired growth. The assumption that achieving growth first, and that the effect would later trickle down to alleviate poverty and inequality is rather unrealistic. ${ }^{14}$

Discussions on inclusive growth would be incomplete without a mention of structural transformation. In the words of Matusyama (2008), "structural change is a complex, intertwined phenomenon, not only because economic growth brings about complementary changes in various aspects of the economy, such as the sector compositions of output and employment, organization of industry, etc., but also these changes in turn affect the growth process. The transformation from the rural agricultural society to the urban industrial society is just one of many aspects of structural change [...]". History has shown that structural transformation is critical to economic development. There are diverse forms of structural transformation: it could be diversification of the economy from an agrarian-based to manufacturing

\footnotetext{
10 There are ample evidences that have confirmed the positive linkage in the investment in human capital (education and health) and economic growth (see Ravallion 2004; Hull 2009).

11 Expanding economic activities in an economy would not only create jobs but also diversify the economy away from existing activities. It would also lead to stability within the economy. However, there is a long-standing debate on how such transformation can be achieved (Chang and Grabel 2004; SaadFilho 2010 ; CAFOD 2014).

12 The importance of "good and functional" institutions has been identified by the influential paper of Acemoglu et al (2003) and tonnes of later studies. Even though in the measurement of institutions, there is no explicit proxy for inclusive growth, these variables are somewhat related. For instance, voice and accountability empowers the citizenry to demand for the financial activities of their government. The control of corruption, which has been identified to be unfavorable to job creation, would improve the status of the population. Also, a responsible government would not further marginalize the marginalized population. Such government would factor in the preferences of all sections of the population in formulating policies and making decisions. Hence, this type of governance could be termed "government for all".

13 Taxation can be used to achieve this. This would invariably lead to direct transfer and redistribution of income. By taxing multinational companies and high-income earners above small and medium scale enterprises as well as those considered to be poor, the gap between the rich and poor would be drastically reduced. Brazil and Libya are exceptional examples of countries that adopted the policies that would see to the fact that the poor receive financial assistance from the government.

14 Statistics have shown that most countries in SSA have been recording growth rate that is not accompanied by improvement the socioeconomic wellbeing of their populace. A detailed exposition of this is presented in the third section of this study.
} 
based. This is the first stage of transformation process. It could also be as a result of industrialization process of countries. This is evidenced considering the antecedents of China, Japan and South Korea.

Even though, Africa has witnessed major structural transformation as well as industrialization process, this has not translated to expected growth or growth rate compatible with other developing regions in the world. This is to say that structural transformation is not a homogenous process (Osei and Jedwab 2013). Productivity growth is quite essential to structural change and hence economic development. Data reveals that the productivity gap in Africa is about $2.5 \%$. This gap could have been reduced to 1.5, if Africa had similar productivity rate as that of Asia. This gap would have also been reduced to 1.7 should Africa had similar employment rate with Asia. To further drive home the importance of structural transformation, McMillan and Rodrik (2011) while using dataset for 38 developing countries, it was found that structural transformation is growth-enhancing for Asian countries while it is growth-reducing for Africa. ${ }^{15}$

\subsection{Measures of inclusive growth}

Having given an overview of the concept of inclusive growth as well as its determinants, the next area that should be explored is the measurement related issues. Just as there is no consensus as regards a workable definition, measuring inclusive growth suffers similar fate. Ali and Son's (2007) measurement used the concept of social opportunity function based on two conditions: (1) average opportunities available to the population, and (2) how opportunities are shared or distributed among the population. This function gives greater weight to the poor. As such, opportunities created for the poor are more important than the non-poor. The increase in these opportunities would lead to inclusive growth. Anand et al. (2013) built on the Ali and Son (2007) to develop a measure of inclusive growth using a macro social mobility function, following the micro literature on income distribution. Their measure provides a framework to study equity and efficiency together. The measure is equally used to study the dynamics and determinants of inclusive growth in low-income countries and emerging markets. The model assumes that inclusive growth depends on income growth and distribution. Using consumer's theory, income and substitution effect was decomposed into growth and distributional components. The underlying social welfare function must satisfy two properties to capture these features: (1) it is increasing in its argument (to capture growth dimension) and (2) it satisfies the transfer property-any transfer of income from a poor person to a richer person reduces the value of the function (to capture distributional dimension).

\footnotetext{
15 This study does not intend to be elaborate in structural transformation discussion. For more information and elucidation, interested readers should see Greenwald and Stiglitz (2013), Lin (2010, 2012), Rodrik (2010), Stiglitz and Lin (2013), among others. For African based studies, Osei and Jedwab (2013) for Ghana; Adeyinka et al. (2013) for Nigeria and Resnick and Thurlow (2013) for Zambia. An interesting study by Herd (2013) shows how the evolution of the Chinese social policies was able to reduce inequality and hence induce inclusive growth.
} 
The extant literature precludes any attempt to explicate the theoretical association between HCD measures and inclusive growth. This implies ample vagueness in the precise mechanisms through which the effects of HCD is transmitted to inclusive growth. Nonetheless, we lay out a plausible transmission mechanism, which is presumed to work via the fiscal behavior of the government. Specifically, it hinges on the effectiveness of both government tax efforts and government expenditures. On the revenue side, the government has to be able to tax the natural resource rents and allocate the tax revenue productively into the education and health sectors. For government spending, government priorities should be set in such a fashion that is de-linked from the gyration of resource revenues. However, the management of resource wealth in this manner is more difficult than depicted. Some of the challenges include, but are not limited to, the well-known volatility of resource prices; the non-renewable status of some of these natural resources and its implication on the optimality of expenditures; weak institutional quality and attendant narrow fiscal space. ${ }^{16}$ Beyond these, also noteworthy is the time lag between "cause" and "effect" of natural resource rent on inclusive growth. Once government increases her expenditure of these HCD indicators, it takes some time before the effects, if any, on inclusive growth begin to manifest. ${ }^{17}$

\section{Data and trend analysis}

The key variables of interest in this paper are inclusive growth, natural resource rent and government expenditure on human development indicators (education and health). In addition to economic growth being a prerequisite for the attainment of inclusive growth, productive employment has also remained one of the key drivers of inclusive economic growth since employment outcome is an important outcome of inclusiveness. In this regard therefore, we utilize log of GDP per person employed as a proxy for inclusive growth to reflect two factors of average opportunities available to the population and how these opportunities are distributed in the population. Consequently, the government expenditure variable is defined as the log of current operating expenditures in education, including wages and salaries and excluding capital investments in buildings and equipment. The health expenditure on the other hand is measure as log of per capita public health expenditure, which covers the provision of health services (preventive and curative), family planning activities, nutrition activities, and emergency aid designated for health but does not include provision of water and sanitation. More so, labour force and physical capital were measured as log of population and log of gross fiscal capital formation respectively. Control variables included in the analysis are trade openness measured as sum of export and import to GDP and price level (inflation rate). A balanced panel annual data set of 18 SSA countries covering the period of

\footnotetext{
${ }^{16}$ Lundgren et al. (2013) in their study adequately dealt with the problem of natural resource wealth in SSA along the lines of its management, difficulties and solutions.

17 We thank an anonymous reviewer for drawing our attention to this very important point.
} 
1995-2014 would be utilized, and all data are sourced from World Development Indicators (WDI) of World Bank.

Our definition of natural resource rent is akin to that of the World Bank and this variable is proxied by total natural resource rent. In the World Bank definition, natural resources are classified under five categories: oil, natural gas, forest and mineral. The aggregation of these categories yields total natural resource rent, which is measured in proportion to GDP. Thus, Fig. 1 below partitioned countries in SSA to include those whose resource rents as a percentage of GDP is $<10 \%$ (countries in black bars), 10-20\% (countries in yellow bars) and $20 \%$ and above are in red bars.

Figures 2 and 3 below provides on a regional basis, a graphically illustration of average resource rents as percentage of GDP (Fig. 2) and average GDP person employed (Fig. 3). It is only a common sense argument that natural resource endowments provide an opportunity to improve economic growth and alleviate poverty. In this regard one expects that if properly harnessed, natural resource rents have the potential of making growth more inclusive in the SSA countries. With the exception of the Arab, Middle East and countries from North Africa (MENA), natural resource rents, as a percentage of GDP, for SSA is slightly higher than that of other regions.

After the 2000s energy crisis and recent oil discoveries, natural resource boom have contributed significantly to increases in government revenue of SSA, and same is expected to have been used to accelerate economic growth inclusiveness. Paradoxically, Figs. 2 and 3 appears to be going in an opposite directions. On the one hand, growth in the less resource endowed regions such as Europe, Latin America and North America seems to be inclusive on the basis of their impressive GDP per person employed. On the other hand, the use of resource rents in SSA
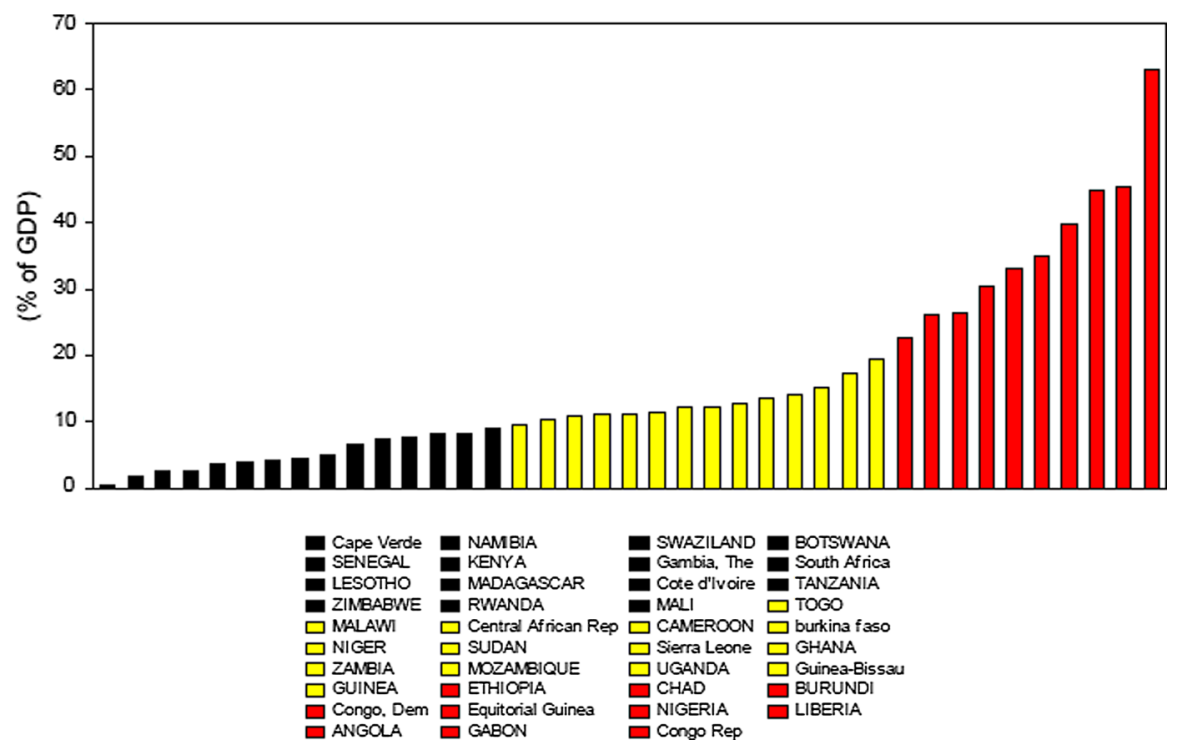

Fig. 1 Average natural resource rents in SSA (1991-2013) 


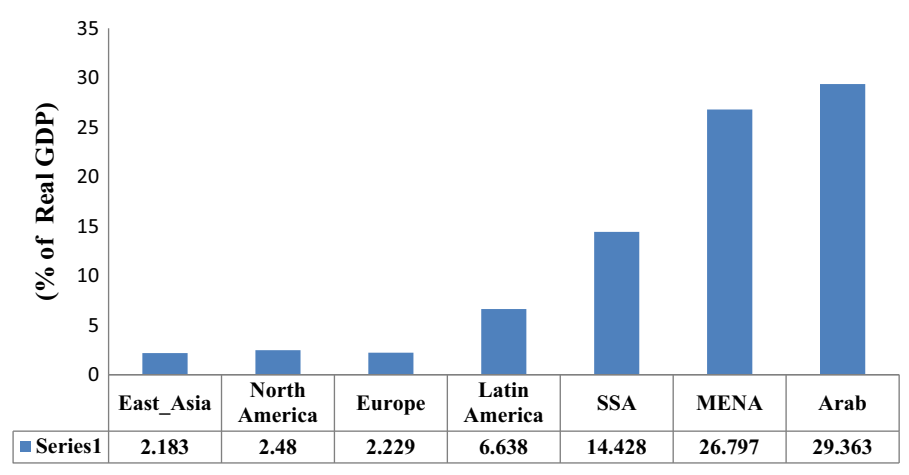

Fig. 2 Average natural resource rent (1991-2013). Source plotted by the authors

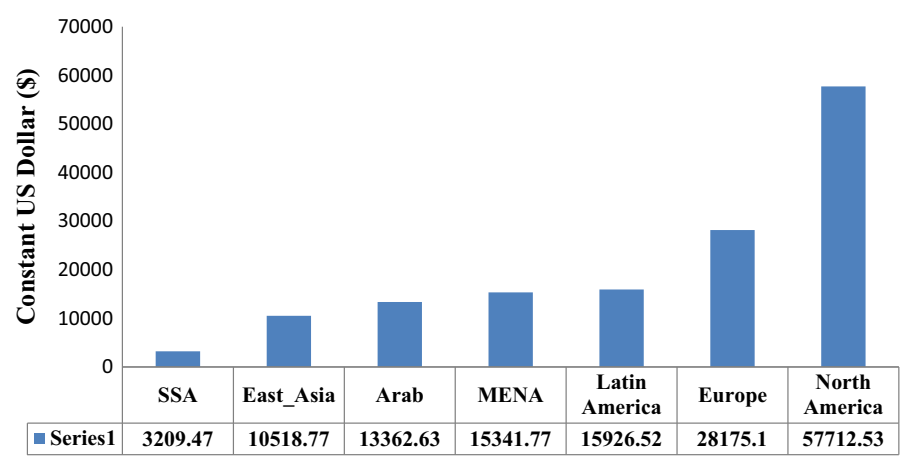

Fig. 3 Average GDP per-person employed (1991-2013). Source plotted by the authors

countries and other resource endowed regions has been disappointing and growth in these regions can be said not to be inclusive especially in the sense of the abysmal level of GDP per person recorded in these resource endowed regions.

Access to health and education and other vital infrastructure such as safe drinking water and adequate sanitation defines the quality of human capital. In order to make the working population possess the human capabilities necessary to be productively employed, investment on human capital development such as spending on health care and education cannot be ignored. For growth to be inclusive, it needs to enhance human capabilities. Also, within the analytical framework of inclusive growth, health and education expenditures can also be utilized as indicators of the degree of equality of opportunity that a country's population enjoys. To this end, we equally demonstrate graphically if available resource rent determines the level of investment in Haman Capital Development (HCD) on regional basis.

Thus, Fig. 4 represents average health expenditure per capita of both the resource rich regions and the less resource rich regions. Not too surprising though, Europe and North America despite being the least resource endowed regions tend to give priority to HCD on the basis of health expenditure than other regions. Specifically, their average per capita health expenditures between 1995 and 2013 are well above 


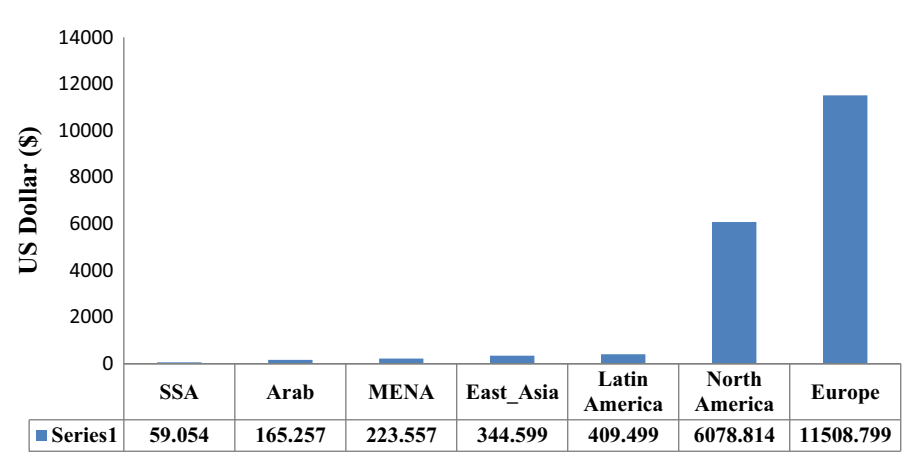

Fig. 4 Average per-capita health expenditure (1995-2013). Source plotted by the authors

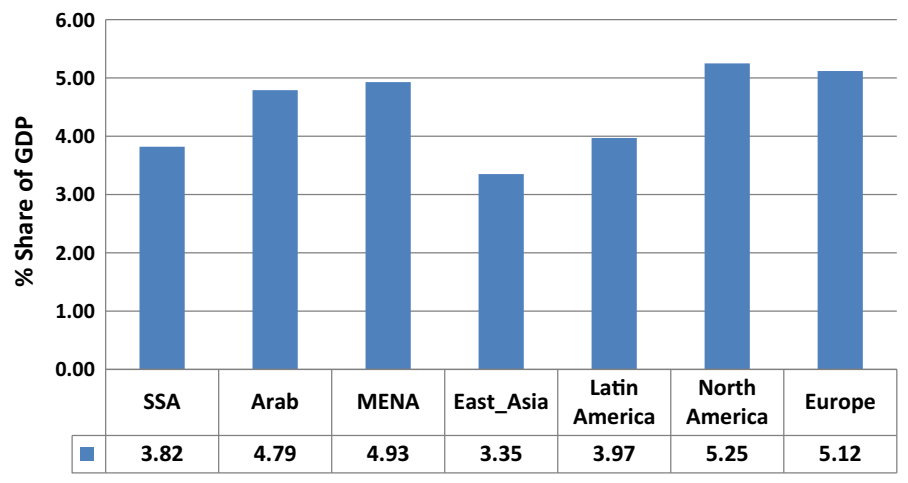

Fig. 5 Average education expenditure as a ratio of GDP (1995-2013). Source plotted by the authors

6000 and 11,000 US dollar, respectively. On the contrary, however, health per capita expenditure in SSA and other resource rich regions such as Arab and MENA are far much lower than 1000 US dollar.

In addition to health expenditure, spending on education is another important means of enhancing the ability of the populace to partake in growth process. Thus, Fig. 5 though depicts oil-producing regions as being relatively impressive in terms of their average education spending in relation to the level of GDP. However, the percentage share of SSA education expenditure to their level of GDP is still relatively lower as compared to other regions with the exception being the East Asia countries. This is an indication that resource rich countries in Sub-Saharan Africa are not only inclusively backward on the basis of their poor GDP person employed, but also in terms of their health and education expenditures.

Among the signs to identify countries with inclusive growth are decline trend of unemployment, poverty, and income inequality. This being the case, citizen would be able to contribute their quota to the national development. Until 2008, the global economy had witnessed massive reduction in rate of poverty and income inequality. A large proportion of this reduction is attributed to the emergence of the "Asian 
Tigers"; notable countries are China, India and East Asian countries. The inverse is the case for the African story.

Figure 6 below presents a graphical illustration of percentage of population living in households with consumption or income per person below the poverty line between 1981 and 2012. The graph shows that SSA recorded highest poverty rate relative to other regions over the years. This suggests that the largest percentage of the population living in households is below poverty line relative to other region. Ironically, the region that is blessed with a lot of natural resource rents could not cater for its citizens. Europe and central Asia that have the least resource endowment could cater for its citizens. This clearly show that the resources meant for the provision of infrastructure and other basic amenities in Sub-Saharan Africa are either mismanaged or embezzled by so called "leader".

Figure 7 depicts the income disparities at a sub-regional level for the regions. The disaggregation of income inequality into sub-region further shows the problem inherent in the African economy. The southern part of Africa recorded the highest level of income disparities among its citizens with Gini indices ranging from 49 to 52. Also, West, East and Central Africa have recorded an increasing uneven distribution of income whereas Southern and North Africa have recorded oscillations resulting in lower Gini Indices from decade of 2000-2009 compared to $1980-1989$.

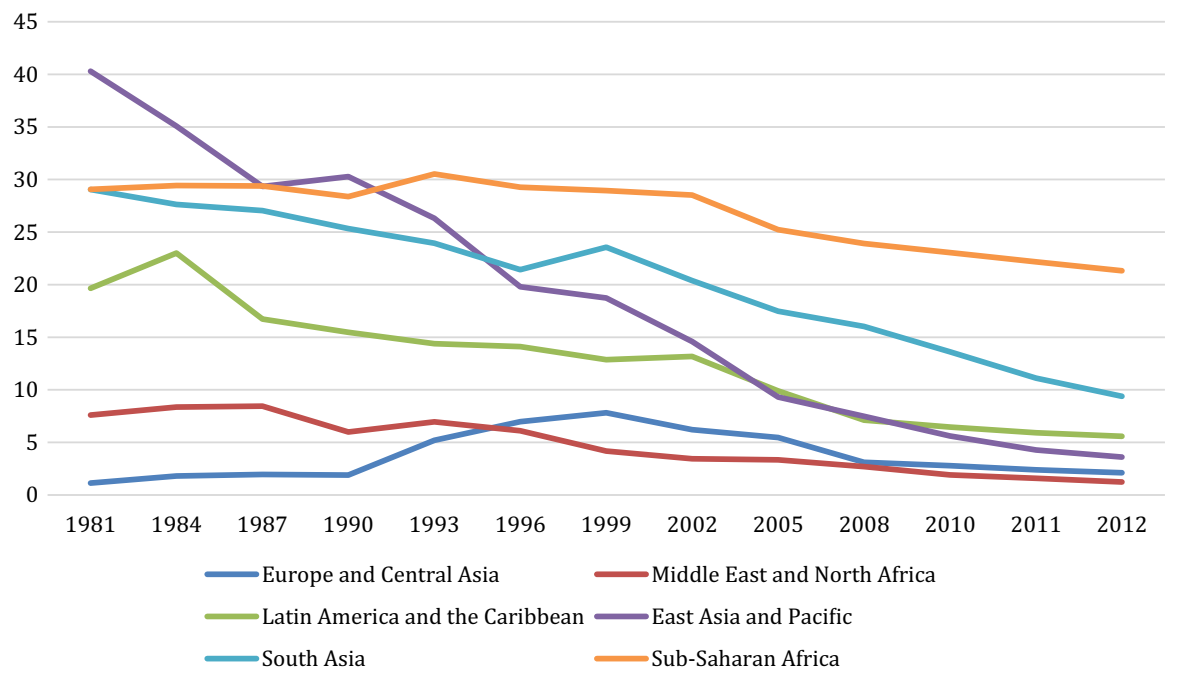

Fig. $6 \%$ of population living in households with consumption or income per person below the poverty line (1981-2012). Note South Asia, East Asia and Pacific and Sub-Saharan Africa values are rescaled by dividing the series by 2 . This is to enable us show the trend clearly because the values of other regions are very small. Source World Bank website using polvcalnet 


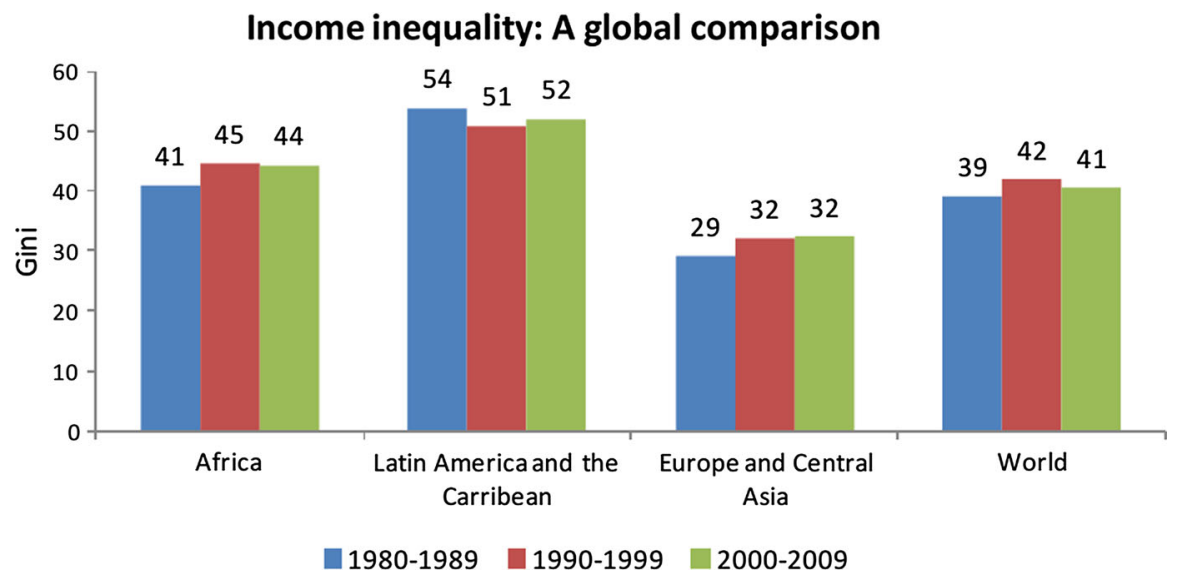

Fig. 7 Income inequality. Source Milcent (2014)

\subsection{Model specification and methodological framework}

Given our desire to account for the contribution of human capital to inclusive growth in SSA, this study adopts an augmented neoclassical model by Mankiw et al. (1992) to empirically evaluate if expenditure on education and health makes growth process inclusive in SSA. To achieve this: (1) we look at the direct effect of government's education and health expenditures as well as natural resource rents on inclusive growth process; and (2) we examine if natural resource rents is important for augmenting expenditures on education and health to enhance the inclusion of human capital for inclusive growth process. In view of this, the baseline equation denoting the inclusive growth model without natural resource rents interaction is represented as follows:

$$
\begin{aligned}
\text { INGROWTH }_{i t}= & \alpha_{0}+\alpha_{1} L A B_{i t}+\alpha_{2} C A P_{i t}+\alpha_{3} E D U_{i t}+\alpha_{4} H L T_{i t}+\alpha_{5} N R S_{i t}+Z^{\prime} \gamma \\
& +\mu_{i}+\varepsilon_{i t}
\end{aligned}
$$

Equation (1) is the baseline inclusive-growth model where $I N G R O W T H_{i t}$ is the $\log$ of GDP per person. The number of countries $i=1, \ldots, N$; the number of periods $t=1, \ldots, T, L A B_{i t}$ is $\log$ of population denoting labour force, $C A P_{i t}$ is the $\log$ of gross physical capital formation representing stock of physical capital, $E D U_{i t}$ is $\log$ of government expenditure on education, $H L T_{i t}$ is $\log$ of health expenditure per capita, $N R S_{i t}$ is total natural resource rents as a percentage of GDP, while $Z$ is a $k \times 1$ vector of control variables. The latter includes inflation rate $\left(I N F_{i t}\right)$ foreign direct investment $\left(F D I_{i t}\right)$ and trade openness $\left(T O P_{i t}\right)$. The regression parameters are $\alpha_{0}, \alpha_{1}, \alpha_{2}, \alpha_{3}, \alpha_{4}, \alpha_{5}$ while $\gamma$ denotes a $1 \times k$ vector of parameters on the control variables; $\mu_{i}$ is the country-specific effect while $\varepsilon_{i t}$ is the regression disturbance term. 
Consequently, the extended inclusive-growth specifications allowing for interaction between the respective conventional growth drivers such as education and health expenditures and natural resource rents is represented in Eq. (2) as follows:

$$
\begin{aligned}
\text { INGROWTH }_{i t}= & \alpha_{0}+\alpha_{1} L A B_{i t}+\alpha_{2} C A P_{i t}+\alpha_{3} E D U_{i t}+\alpha_{4}\left(E D U_{i t} * N R S_{i t}\right)+\alpha_{5} H L T_{i t} \\
& +\alpha_{6}\left(H L T_{i t} * N R S_{i t}\right)+\alpha_{7} N R S_{i t}+Z^{\prime} \gamma+\mu_{i}+\varepsilon_{i t}
\end{aligned}
$$

As shown in Eq. (2), in order to verify if natural resource rents enhances the inclusion of human capital in growth process in SSA, we interact growth determinant variables namely education and health expenditures with natural resource rents $\left(N R S_{i t}\right)$.

To complement this study, we further adopt a simulation methodology based on the intuition that human capital is a key driver of growth in an economy. Following this logic, we estimate the potential growth that is accruable by increasing government expenditure on health and education. We argue that natural resource rent should fund these expenditures. ${ }^{18}$ It is assumed that in the process of increasing government expenditure, more jobs would be created, investment increases, which thus increase tax-based revenue of the government. This would invariable boost capital formation, which is part of the key drivers of long-run economic growth. In an attempt to capture this, we use the incremental capital output ratio (ICOR) derived from historical values of government expenditures on health and education.

We draw inferences and inspiration from the financing gap model, which is known to be useful for forecasting and policy simulations. International organizations such as the World Bank and the United Nations have based their simulation policies on this model. Despite its laudable advantage, it is not free from criticism. First, there is no direct relationship in the variables used for simulation or forecasting (i.e. it is not every dollar spent on education or health would yield extra growth). Second, the principles of ICOR assume linearity between and/or among variables of interest. The first problem can be addressed using historical data on government expenditure on education and health as well as growth. Using historical data also partly help address the concern that some expenditure might be driven by bad policies. The second criticism is about the precision of point estimates; this is less of a concern about estimates of the average impact over a long period. Nonetheless, the simulation results should be interpreted with caution. That is, they are only illustrative and useful in providing an order of magnitude rather than precise estimates of the impact.

Based on the foregoing, the first step is to calculate ICOR that measures the amount of expenditure needed to produce one extra unit of growth. ICOR is calculated given the formula below:

$$
I C O R_{i t}=\frac{\text { Gov.Expenditure }_{i t}}{\text { GDP_Growth }}
$$

\footnotetext{
18 Since government have different sources of income, channeling resource rent on the two sectors of the economy would not have adverse effect on the rest of the sectors provided government can diversify their source of income away from the depending on proceeds from natural resources.
} 
It should be noted that some countries might experience negative growth, which thus might produce negative values for ICOR, which does not have any empirical meaning. Hence, we used the absolute value of ICOR. It is a known fact that trend of economic growth rate of African countries are susceptible to volatility. This problem is addressed using the median value of ICOR over a period of time as against the estimated annual values. In specific reference, we used the 5-year nonoverlapping periods, except the last period that has 4 years.

Using Eq. (3) and assuming that natural resource rent would produce the same output per dollar as historical values of government expenditure, the additional output resulting from investing the resource in rent is given as follows:

$$
\Delta G D P_{i t}^{\prime}=\frac{R E S_{i t}}{I C O R_{i}}
$$

The potential GDP, which is the level that would be achieved by increasing government expenditure, is given as:

$$
G D P_{i t}^{*}=\Delta G D P_{i t}^{\prime}+G D P_{i t}
$$

The last stage is to calculate the potential growth of output per capita by comparing the potential output growth with actual or historical data. This is achieved by implanting the formula below:

$$
g_{t}^{*}=\left(\sum_{0}^{T} \frac{G D P_{t}^{*}}{G D P_{t}} * 100 \%\right) / T ; \text { where } \mathrm{T} \text { is } 5 \text { years. }
$$

\section{Empirical results}

\subsection{Panel models regression results}

The empirical outcomes resulting from the estimation of the three static panel models considered however, reveals fixed effect as the preferred model to the pooled and random effect models. This is as a result of the significance of both the *F-statistic and the Hausman test prompting the rejection of the null hypothesis on both instances. To this end, we are statistically constrained to concentrate on discussing the practical and empirical implications of estimates from the fixed effect model only.

Thus, the empirical result in Table 1 below shows that inclusive growth in SSA countries can be positively and significantly enhanced by human capital development via spending on education and health cares. The magnitude of this association seems be more pronounced when the natural resource rent is interacted with health expenditure, while the interaction between natural resource rent and education expenditure constitute inclusive growth drag (though this is insignificant).

Hence, the economic implication of the above empirical findings is that, inclusive growth in SSA countries can be amplified through government spending on 
Table 1 Empirical results of inclusive growth models

\begin{tabular}{|c|c|c|c|c|}
\hline \multirow{2}{*}{$\begin{array}{l}\text { Table } 1 \text { Empirical results of } \\
\text { inclusive growth models }\end{array}$} & \multirow[t]{2}{*}{ Variable } & \multicolumn{3}{|c|}{ Fixed effect model } \\
\hline & & Coefficient & Standard error & T-stat. \\
\hline & \multicolumn{4}{|c|}{ Dependent variable: log of GDP per person (inclusive growth) } \\
\hline & Constant & $6.523 * * *$ & 0.108 & 64.02 \\
\hline & CAP & 0.012 & 0.019 & 0.71 \\
\hline & LAB & $-0.203^{*}$ & 0.055 & -1.51 \\
\hline & EDU & $0.082^{* *}$ & 0.035 & 0.52 \\
\hline & HLT & $0.112^{* *}$ & 0.049 & 2.55 \\
\hline & NRS & $0.033^{* *}$ & 0.005 & 2.20 \\
\hline & FDI & $0.293 * *$ & 0.067 & 2.49 \\
\hline & INF & $0.0002 * *$ & 0.0001 & 2.02 \\
\hline & TOP & 0.0004 & 0.0006 & 0.63 \\
\hline & EDU*NRS & 0.045 & 0.001 & 1.34 \\
\hline & $\mathrm{HLT}^{*} \mathrm{NRS}$ & $0.078^{* *}$ & 0.002 & 2.16 \\
\hline & \multicolumn{4}{|c|}{ Diagnostic statistic } \\
\hline & Countries & \multicolumn{3}{|l|}{18} \\
\hline & Observation & \multicolumn{3}{|l|}{342} \\
\hline & $\mathrm{R}$-squared & \multicolumn{3}{|l|}{0.476} \\
\hline & F-statistic & \multicolumn{3}{|l|}{$52.38 * * *$} \\
\hline & *F-statistic & \multicolumn{3}{|l|}{$213.96^{* * *}$} \\
\hline $\begin{array}{l}* * * * * \text { and } * \text { implies significant } \\
\text { at } 1,5 \text { and } 10 \%\end{array}$ & Hausman test & \multicolumn{3}{|l|}{$17.55^{* *}(0.041)$} \\
\hline
\end{tabular}

$* * *, * *$ and $*$ implies significant at 1,5 and $10 \%$

education and health care over the period under consideration. What this implies is that inclusive growth in SSA requires more than just large size of labour force; but labour force with quality to be complimented with available capital stocks. More importantly also, inclusive growth in the region can be attained directly via effective allocation of resource rents even though using it to augment spending on human development via health expenditure increases the inclusiveness impacts of resource rents on growth process in SSA.

In sum, the view that human capital development via spending on education and health conclusive can aid the attainment of inclusive growth tends to be supported by the panel evidence reported in this study. Also, the statistical significant of both the direct and indirect impacts of resource rents on inclusive growth process as shown in our empirical report is to a meaningful extent, an indication that development of human capital for the attainment of growth inclusiveness can be fostered through effective allocation of resource rents in SSA.

\subsection{Simulation exercise}

The comprehensive report of the simulation exercise, which is meant to complement the results of the estimated panel model, is presented in Table 2. Precisely, the study based the simulation results on the assumption that the total natural resource revenue are spent on health sector. The exclusion of the education is due to its 
insignificant coefficients when interacted with natural resource rent. The result of the simulation exercise show that on the average, the region could have had an increased GDP per capita on about $3 \%$. Among the top gainers are Senegal, Ethiopia and Mozambique. It is puzzling to infer that countries such as Congo, DR and Cote d'Ivoire would experience growth drag should they embark on increasing government expenditure in the health sector. On the average, countries like Madagascar and Kenya have no incentive into improvement government expenditures on the health sector. A plausible reason for these scenarios is difficult to infer.

\section{Conclusion}

The study considered empirical analysis of inclusive growth, human capital development and natural resource rents in SSA. It utilizes all the three classes of static panel model to examine if, augmenting education and health expenditure with natural resource rents in SSA would be significant for making growth process inclusive. In addition, a financing gap model was further employed to estimate the potential growth in GDP per capita that is accruable to the economy if government use natural resource rent to finance increase in health expenditure.

Table 2 Simulation exercise. Source authors' computation

Ave is Average; Act is Actual, Pot meant Potential, Addi stands for Additional, Education expenditure while Hea is health expenditure per capita

\begin{tabular}{|c|c|c|c|c|}
\hline Country & Ave Hea & Ave act GDP & Pot GDP & Addi GDP \\
\hline Burkina Faso & 25.101 & 399.063 & 407.198 & 2.039 \\
\hline Cameroon & 43.068 & 896.216 & 902.409 & 0.691 \\
\hline Congo, Dr & 9.978 & 241.142 & 235.943 & -2.156 \\
\hline Cote d'Ivoire & 60.828 & 1024.82 & 1024.652 & -0.016 \\
\hline Ethiopia & 9.635 & 178.803 & 194.812 & 8.953 \\
\hline Ghana & 40.798 & 521.253 & 528.845 & 1.456 \\
\hline Kenya & 25.846 & 539.316 & 540.889 & 0.292 \\
\hline Madagascar & 14.861 & 277.513 & 277.623 & 0.039 \\
\hline Malawi & 18.305 & 227.608 & 229.342 & 0.762 \\
\hline Mali & 30.703 & 429.247 & 434.862 & 1.308 \\
\hline Mozambique & 19.321 & 300.046 & 310.54 & 3.497 \\
\hline Niger & 17.342 & 268.478 & 268.935 & 0.170 \\
\hline Nigeria & 57.942 & 758.567 & 772.035 & 1.775 \\
\hline Senegal & 35.553 & 738.369 & 972.278 & 31.679 \\
\hline South Africa & 397.819 & 5366.857 & 5400.798 & 0.632 \\
\hline Sudan & 55.69 & 818.504 & 841.734 & 2.838 \\
\hline Tanzania & 19.846 & 434.476 & 441.583 & 1.636 \\
\hline Uganda & 34.136 & 320.403 & 327.103 & 2.091 \\
\hline Zambia & 44.772 & 751.602 & 761.873 & 1.367 \\
\hline Average & 50.674 & 762.751 & 782.813 & 3.108 \\
\hline
\end{tabular}


Using dataset for 18 SSA countries, it was found that education and health are good determinants of inclusive growth. This however, appears to be more significantly pronounced when the interaction is between health expenditure and natural resource rent. Results of the simulation exercise show that SSA would have had a potential GDP per capita growth of about $3.1 \%$. It was also established that countries with relative higher GDP per capita (for instance, South Africa and Cote d'Ivoire) tend not to benefit from the additional increase in government expenditure on health.

The policy relevance of this study suggests that in an attempt to enhance inclusive growth, it is imperative for government to increase expenditure on education and health. This being the case, the productivity level of the country would increase, investment would be on the rise, and employment generation would soar, which thus increases tax-based revenue of the government. Hence, an attempt to increase government's investment in these sectors would further generate additional revenue for the government. It can be stated that the effect of increase in government expenditure is a vicious cycle. Hence, it is important for government to focus on improving her expenditure on health.

This study was unable to provide explanation for the reason why countries with relative higher GDP per capita tend not to benefit from increasing government expenditure. Based on this, an interesting area where future research can beam the search light on is the level of income at which increase in government expenditure ion education and health would ensure growth and development. By this, it is implied that future studies should verify the existence of a threshold effect (if any) between government expenditures and national income level. Lastly, a very promising area future studies should focus their beam light on is the time lag between "cause" and "effect" of natural resource rent on inclusive growth.

Open Access This article is distributed under the terms of the Creative Commons Attribution 4.0 International License (http://creativecommons.org/licenses/by/4.0/), which permits unrestricted use, distribution, and reproduction in any medium, provided you give appropriate credit to the original author(s) and the source, provide a link to the Creative Commons license, and indicate if changes were made.

\section{References}

Acemoglu D, Johnson S, Robinson JA, Thaicharoen Y (2003) Institutional causes, macroeconomic symptoms: volatility, crises and growth. J Monet Econ 50(January):49-123

Addison T, Nino-Zarazua M (2012) What is inclusive growth? Nordic-Baltic MDB meeting. UNUWIDER, Helsinki

Adeyinka A, Salau S, Vollrath D (2013) Structural change in Nigeria. Unpublished Manuscript, Department of Economics, University of Houston

Ali I, Son H (2007) Defining and measuring inclusive growth: application to the Philippines, ERD working paper series no. 98. Asian Development Bank

Anand R, Mishra S, Peris S (2013) Inclusive growth: measurement and determinants, IMF working paper WP/13/135

Arezki R, Nabli MK (2012) Natural resources, volatility, and inclusive growth: perspectives from the Middle East and North Africa, International monetary fund working paper WP/12/111

Arezki R, Dupuy A, Gelb A (2012) Resource windfalls, optimal public investment and redistribution: the role of total factor productivity and administrative capacity. International monetary fund working paper WP/12/200 
CAFOD (2014) What is "inclusive growth"? CAFOD discussion paper, August Version, pp 1-17

Chandy L, Penciakova V (2013) The final countdown: prospects for ending extreme poverty by 2030. Brookings Institute, Washington, DC

Chang HJ, Grabel I (2004) Reclaiming development: an alternative economic policy manual. Zed Books. In: Arezki R, Pattillo C, Quintyn M, Zhu M (eds) Commodity prices and inclusive growth in lowincome countries. International Monetary Fund, Washington, DC

Frankel JA (2012) The natural resource curse: a survey of diagnoses and some prescriptions, HKS faculty research working paper series RWP12-014, John F. Kennedy School of Government, Harvard University

G20 (2013) G20 leaders declaration, St Petersburg, September 2013. http://bit.ly/1nI3Mge growth, NBER working paper no. 5398. National Bureau of Economic Research, Cambridge. http://papers.nber.org/ papers/w5398

Greenwald B, Stiglitz JE (2013) Industrial policies, the creation of a learning society, and economic development. In: Stiglitz JE, Lin JY (eds) The industrial policy revolution I: the role of Government beyond ideology, pp 43-71, Macmillan, Basingstoke

Herd R (2013) The evolution of China's social policies. Econ Change Reconstr 46:109-141

Heuty A (2012) The role of transparency and civil Society in managing commodities for inclusive growth and development. In: Arezki R, Pattillo C, Quintyn M, Zhu M (eds) Commodity prices and inclusive growth in low-income countries, International Monetary Fund. http://bit.ly/1kBamUk

Hull K (2009) Understanding the relationship between economic growth, employment and poverty reduction. In: Promoting pro-poor growth: employment. OECD, Paris

Ianchovichina E, Gable SL (2012) What is inclusive growth? In: Arezki R, Pattillo C, Quintyn M, Zhu M (eds) Commodity prices and inclusive growth in low-income countries. International Monetary Fund, Washington, DC

Lin JY (2010) New structural economics: a framework for rethinking development, Policy research working paper 5197. World Bank, Washington, DC

Lin JY (2012) The quest for prosperity: how developing economies can take off. Princeton University Press, Princeton, NJ

Lundgren CJ, Thomas AJ, York RC (2013) Boom, bust, or prosperity? managing Sub-Saharan Africa's natural resource wealth, IMF working paper series

Mankiw NG, Romer D, Weil D (1992) A Contribution to the empirics of economic growth. Q J Econ 107(2):407-438

Matusyama K (2008) Structural change. In: Durlauf NS, Blume LE (eds) The New Palgrave dictionary of economics. Palgrave Macmillan, Basingstoke

McMillan MS, Rodrik D (2011) Globalization, structural change and productivity growth (No. w17143). NBER, New York

Milcent C (2014) The effect of financial development on income inequality in Africa: looking for a needle in a haystack?. Jonkoping University, Jonkoping International Business School, Jönköping

OECD (2012) OECD employment outlook. OECD, Paris

OECD (2013a) Report on addressing base erosion and profit Shifting. OECD, Paris

OECD (2013b) Speech by OECD secretary general angel Gurria, at OECD workshop on inclusive growth, Together we stand: inclusive growth. Paris, 3 Apr 2013

OECD (2013c) OECD secretary general angel Gurriaopening remarks to OECD Forum 2013: "people first!" Paris. 28 May 2013

Osei RD, Jedwab R (2013) Is structural change in Sub-Saharan Africa different? New historical evidence from Ghana in 1960-2010

Oxfam (2014) Working for the few: political capture and economic inequality. Oxfam, Oxford. http://bit. ly/1bcqZvj

Oyinlola MA, Adeniyi O, Raheem ID (2015) Natural resource abundance, institutions and economic growth in Africa. Afr J Econ Sustain Dev 4(1):34-48

Ravallion M (2004) Pro-poor growth- a primer. World Bank, Washington, DC

Ravallion M (2009) Do poorer countries have less capacity for redistribution? Policy research working paper 5046. World Bank, Washington, DC

Resnick D, Thurlow J (2013) The political economy of Zambia's recovery: structural change without transformation?

Rodrik D (2010) Globalization, structural change and productivity growth, NBER working paper no. 17143 
Saad-Filho A (2010) Growth, poverty and inequality: From Washington consensus to inclusive growth, DESA working paper no. 100, pp 1-22

Sachs JD, Warner AM (1995) Natural resource abundance and economic growth, NBER working paper no. 5398. National Bureau of Economic Research, Cambridge. http://papers.nber.org/papers/w5398

Stiglitz JE, JY Lin (eds) (2013) The industrial policy revolution I: the role of government beyond ideology, Palgrave Macmillan, New Yor, forthcoming

Warner A (2012) Inclusive growth in natural resource intensive countries. In: Arezki R, Pattillo C, Quintyn M, Zhu M (eds) Commodity prices and inclusive growth in low-income countries. International Monetary Fund, Washington, DC

World Bank (2006) World development report 2006: equity. World Bank, Washington, DC

World Bank (2012) Inequality in focus, introduction to the inequality in focus series. World Bank, Washington, DC

World Bank (2013) World development report 2013: Jobs. World Bank, Washington, DC 